\title{
Fluid Identities and Social Dislocation IN THE FACE OF CRIME, GUILT AND ETHICS in Patricia Highsmith's The Talented Mr Ripley AND THE TREMOR OF FORGERY
}

\begin{abstract}
The purpose of this article is to examine identity shift and social alienation in different social and cultural backgrounds in the two works of Patricia Highsmith (1921-1955) - The Talented Mr Ripley (1955) and The Tremor of Forgery (1969). The emphasis will be placed on the exploration of crime, guilt and human conscience in confrontation with new environments and ethically different cultural norms. The article will show that Patricia Highsmith's novels, despite each depicting entirely different social and cultural environments, address the problem of identity, ethics and guilt in crisis situations. As a lesbian, the American writer was imbued with a feeling of social non-conformity, and her status as an American living in Europe also marginalized her. Patricia Highsmith's living in deeply conservative American society affected her writing and contributed to the creation of the characters who operate outside the norm and live on the fringes of society.
\end{abstract}

\section{Keywords}

Patricia Highsmith; identity; outsider; guilt; crime; ethics

Patricia Highsmith (1921-1995), the distinguished American novelist, short story writer and essayist, is renowned for her exploration of the psychology of guilt and abnormal behaviour of men in unpredictable, adverse circumstances. Her novels frequently deal with questions of split and fading identity, double personality, a man's cultural dislocation and dissociation from society. Highsmith was known in her time as a gifted genre writer, a psychological crime novelist with style and penetrating depth of vision (Cassuto 2009: 134). Her two most notable works, 
Strangers on a Train and The Talented Mr. Ripley which feature sociopaths and murder were made into successful movies, the first by Alfred Hitchcock in 1951 and the second by René Clément in 1960, under the title Plein Solei (Purple Noon), as well as in 1999 with Matt Damon and Jude Law. Described by Graham Green as a "poet of apprehension," who "created a world of her own - a world claustrophobic and irrational which we enter each time with a sense of personal danger," she occupied a respectable niche in American crime writing circles before her reputation began to rise following her death (Greene 1970: x). Despite the fact that Highsmith defied simple categorisation in her violent, complex, psychologically stimulating novels, she is mostly credited for her psychological thrillers, which contributed to a number of film adaptations and gained her much acclaim in the literary world.

Social and cultural dislocation, personality crisis and identity shift have been crucial issues thoroughly examined by a number of critics. Authors like Edward Said (2000), Judith Howard (2000) or Maria del Mar Ramon Torrijos (2012) scrutinise the problem of dislocation and alienation frequently with reference to race, gender, sexuality and the psychology of crime. Nonetheless, it is the existential void and ethics of crime explored by Dostoevsky who captured the curious machinations of the mind (Notes from Underground, 1864, Crime and Punishment, 1867), Kafka's tragic humanism and spiritual isolation (The Trail, 1925, "A Hunger Artist", 1922), along with Sartre's existentialist anxiety ("Existentialism and Humanism", 1946), which mostly shaped Patricia Highsmith's "dislocated" and existential protagonists. The American author's exploration of desolated and socially marginalised heroes, often being murderers, criminals, or characters living on the fringe of the society, closely reflects her own grave, complex situation as a lesbian writer living in the ultra-conservative country. Critics like Maria del Mar Ramon Torrijos (2012: 61) draw attention to lesbian detective fiction which offers a fundamental challenge to the accepted conventions of detection genre by firstly placing a female character in a traditional male role and secondly allowing her to transgress the conservative heterosexual norms of sexuality and identity. Although the majority of Highsmith's characters are men and her novels assume a masculine perspective of existence, the writer offers a subversive social and cultural critique which reveals patriarchal authority and rigid sexual stereotypes.

Highsmith's novels and stories, largely influenced by Fyodor Dostoyevsky, Soren Kierkegaard, Friedrich Nietzsche, Franz Kafka, Jean-Paul Sartre and Albert Camus, reflect existential concerns by envisioning a modern world filled with bedlam, absurdity and preposterousness. Similar to the solitary individual scrutinized and extolled by existential writers and philosophers, Highsmith's protagonists are cut off from previously secure bearings of community, habit, tradition, and religious assurance and placed in crisis situations where they must nakedly face reality, confront and answer absolute questions of identity, ethics, faith and death (Sartre 1947: 27). These characters, though often dwelling in luxurious apartments and grand mansions, are portrayed as the prisoners of their wealthy domestic cells, and their vagabond lifestyles, eccentricity and deviation from so- 
cially accepted norms are viewed as hazards to the domestic harmony and peace enjoyed by most "ordinary" American citizens.

Patricia Highsmith viewed herself as an expatriate during her travels to Europe, and a rootless, pervasive angst nourished her paranoid creative vision. The writer's feelings of desolation are frequently reflected in her works and aid in the creation of her characters and the depiction of the place. In fact, Highsmith's sense of loneliness and estrangement significantly affects her picturing fictional homes which stand for refuges, hiding places, mansions and castles, and are often featured as full-blown characters ("Patricia" 2006).

Nevertheless, the author particularly suffered from cultural dislocation and experienced social alienation in non-European environments, mostly in Africa. African countries represent self-imposed exile in her writing and the strangeness of the environment dramatically affects social communication, leading to the shift and reconstruction of identities as well as raising the issues of moral limits and transgressions.

The purpose of this article is to scrutinise the problem of social dislocation, personality crisis, reconstruction and shift of identities in new socio-cultural contexts in Patricia Highsmith's two novels - The Talented Mr Ripley (1955) and The Tremor of Forgery (1969). The focus of analysis is on crime, guilt, human conscience and ethics in confrontation with new, unfamiliar environments and different cultural norms. Despite the fact that the two works reflect dissimilar themes and structures as well as depicting entirely different, social and cultural backgrounds, they both, in fact, address the problem of identity, split and double personality, ethics, morality and guilt in the face of new unforeseen circumstances and critical situations. Moreover, it is worth remarking that both books share the qualities of thrillers, yet they defy simple categorization since Highsmith is regarded as an utterly unique genre writer, a master of creating apprehension whose works offer cruel, sadomasochistic pleasures.

The central themes of the first of the above-mentioned texts are the flux-like nature of identity and a reconstruction of self in the face of crime and moral justice. The Talented Mr. Ripley is distinguished as a psychological thriller in which the novelist created her most popular, appealing and enduring character, the anti-hero Tom Ripley. The novel is an in-depth study of a young, poor, yet ambitious American who attempts to enhance his socio-economic status in Europe by murdering his wealthy friend and assuming his identity. The author vividly illustrates the protagonist's spatial and spiritual journey from his miserable life in a small American town to a lavish lifestyle in luxurious, culturally stimulating European cities. Nonetheless, despite Tom Ripley's fascination with Europe, especially with the prospect of living there in luxury and peace, his status as an outsider is fairly noticeable and the protagonist constantly suffers from splintered identity, insecurity, inferiority and obsession with maintaining an adequate standard of living.

Highsmith's most famous - and ambivalent - protagonist appeared in several sequels, among them Ripley Under Ground (1970), in which he both masquerades 
as a dead painter and kills an art collector, Ripley's Game (1974), a story of revenge, in which the protagonist is paired with a first-time murderer, The Boy Who Followed Ripley (1980), and Ripley Under Water (1991), the character's final adventure, in which Ripley is pursued by a sadistic American, who knows too much of his past. Despite a huge popularity of The Ripliad, it is The Talented Mr. Ripley that has drawn readers' and literary critics' special attention due to the author's dexterous depiction of a bisexual serial killer who, like Dorian Grey, lives a double life, yet remains unpunished for his actions. In contrast to The Tremor of Forgery, this story was made into successful movies, first by René Clément in 1960 under the title Plein Solei (Purple Noon) and secondly by Anthony Minghella in 1999. It is worth remarking that the two movies, albeit each being unique and innovative, are still devoid of deep psychological complexity in presenting tense and frenetic relationships between the two male characters, as visible in Highsmith's novel. It is apparent especially in Minghella's film which accentuates the eponymous hero's homoerotic attraction to his friend, in contrast to the book illustrating the protagonist's more complex and ambiguous relation with his friend, his emotional closeness and endeavour to assume his identity. Contrastingly, Clément's film adaptation offers a more in-depth profile in the analysis of the characters involved. Nevertheless, here, the criminal is brought to justice, unlike in Highsmith's novel which reflects the author's disinterest in the public passion for justice, but rather her fascination with the amorality and psychological disintegration of the eponymous hero. Thus, the two adaptations of Highsmith's novel, next to her other novels, such as Strangers on a Train (1951), illustrate various directors being unsuccessful in challenging the writer's novels. In The Talented Mr Ripley, Highsmith skilfully perverts the workings of sympathy towards the main characters by depicting them and their relations as queer and bizarre, in contrast to the movies which influence the audience's attitudes towards characters, their feelings, moral considerations and physical point of view (sharing a character's field of vision) (Rubin 219).

The Talented Mr. Ripley constitutes a profound psychological analysis of a protagonist, a charming criminal of intelligence who goes unpunished for the murder of his wealthy and influential friend, Dickie Greenleaf. Ripley became Highsmith's most enduring character, who could be regarded as a sadist and an understanding husband, a parody of upper-class mentality and a criminal only by force of circumstances. It is interesting to notice how the author seduces us into identifying with her villain and sharing his selfishness. In Highsmith's story Ripley is convinced that getting his own way is worth whatever price anyone else might have to pay, and it seems that there is a little of this egocentricity in each of us. Moreover, the author depicts the main character as strongly attracted to another man, and expresses his obsession with crime. Although it is not overtly stated, there is an allusion to homoerotic attraction - the criminal essentially wants to become the other man and assume his identity. What is more, by creating and portraying the main characters as gay criminals the author endeavours to suggest how this criminality results from restrictions placed on homosexuals, and by as- 
suming the queer, or abnormal perspective of a gay man her novels imply how violence and criminality can proceed from repressive sexual norms (Hart 2011). Hence, according to Patricia Highsmith, repressed emotions may lead to murder.

Tom Ripley's inhibitions in the sexual sphere and social interaction as well as his desperate attempts to change his material and class status result from his traumatic childhood experience, lack of genuine parental guidance, domestic warmth and stability. The protagonist's 'weird' and 'eccentric' behaviour, attributed to his homosexual inclinations, along with his vagabond lifestyle and lack of professional stability, threatened American norms and standards during an age of conformity, marked by the Red Scare and the Cold War. Nevertheless, Tom Ripley enjoys complete impunity after committing two crimes. His obsession to change his social status, assume the identity of his rich friend, inherit his fortune and enjoy domestic peace is a desperate attempt to build his own home, restore order to his life and expunge the memory of his painful childhood. As was mentioned before, Ripley is an American who spends most of his time in Europe, however, he feels like an outsider and a rootless stranger there. Like Highsmith, who often travelled to Europe during the 1950s, nourishing her view of herself as an expatriate and an outsider, the eponymous character of The Talented Mr Ripley makes frequent trips around Europe, yet he never feels fully satisfied with one location, therefore he frequently changes it, mostly out of fear of being recognised by the local police. It is Europe, however, where Tom successfully escapes justice and is not convicted of murder. While being there, "it meant he was not suspected at all. It meant that the fingerprints really had guaranteed his innocence. It meant not only that he was not going to jail, and not going to die, but that he was not suspected at all. He was free" (Highsmith 1955: 247). On the other hand, while being in Greece, Ripley imagines himself at his next stop in Crete, fleeing police who are "patiently waiting for him with folded arms (Highsmith 1955: 145). This implies that he may be in constant danger, and the fact that he may not find peace on the island of Crete, the site of the labyrinth of ancient mythology and Tom's final stop in the novel, reinforces the protagonist's entrapment and reflects his status of an outsider.

From the opening pages of the novel, Tom is portrayed as a character in search of adventure and hazard. In the first section of the book the protagonist travels to Europe in a twisted reworking of Henry James's The Ambassadors. This enables Tom to overcome the limitations of the country of his birth and provides his creator with the means to illustrate his American psyche from a distance. Thus, Highsmith's transplanting of her anti-hero into foreign soil not only catalogues the differences between Europe and the United States but also shows the ways in which this distance influences her characterisations (Peters 2011: 147). Patricia Highsmith shows the protagonist's startling transformation from an inhibited, poverty-stricken youngster into a self-confident, unscrupulous man who, by using his exceptional 'talent' and manipulation, transcends the strictures and limitations of the United States and realises his ambitions in Europe. After murdering Dickie and taking over his identity, Tom strives to live a stable life and 
to build his dream home, having 'inherited' Greenleaf's fortune. Ripley gains material success largely thanks to his chameleon-like features and a multitude of talents, especially his mathematical aptitude and "proleptic imagination" (Tuss 2015). In a conversation with Dickie, Tom boastfully states: "I can do a number of things - valeting, baby-sitting, accounting - I've got an unfortunate talent for figures. I can forge a signature, fly a helicopter, handle dice, impersonate practically anybody, cook - and do a one-man show in a nightclub in case the regular entertainer's sick" (Highsmith 1955: 51). Since the author does not provide any adequate psychological 'explanation' for Ripley's acts of crime, apart from his desire to gain material success and improve his social status, the protagonist remains a chameleon-like imitation of a human being, a hollowed-out version of Kierkegaard's synthesis of ethical choice (Peters 2011: 156).

Ripley believes that killing Greenleaf is a turning point in his life since it marks the real annihilation of his past and of himself as well as contributes to his rebirth as an entirely new person. Critics such as Cassuto observe that Highsmith links the scene of Dickie's murder with crucifixion imagery. In the novel crime entails a perversion of the sacrifice of Christ. In view of this, Tom's act of murder is his sacrifice and resurrection, taking his self-renunciation to an absolute limit (Cassuto 2009: 142). One may notice that after the crime, the 'new-born' Ripley painfully struggles to find himself within a new milieu. After committing the crime he is able to function within everyday social situations, although with an air of coldness and detachment. Nonetheless, his working-class upbringing, destitution, lack of cultural refinement among his New York friends alienate him from his predominantly rich, middle-class European companions. A sensation of desolation and social dislocation distances him from the inhabitants of France, Italy and Greece and diminishes his relationships with them:

But he was lonely $[\ldots]$ he had imagined himself acquiring a bright new circle of friends with whom he would start a new life with new attitudes, standards and habits that would be far better and clearer than those he had had all his life. Now he realized that it couldn't be. He would have to keep a distance from people, always. He might acquire the different standards and habits, but he could never acquire the circle of friends. (Highsmith 1955: 159)

By and large, The Talented Mr Ripley is a psychological novel which addresses the issues of impersonation, the substitution of one identity for another, the forgery of personality and the fluidity of character. By creating her most memorable anti-hero who transcends the limitations of the United States and realises his social cultural and later artistic aspirations in Europe after committing the crime, Highsmith skilfully plays with the expectations of her readers and fails to satisfy their demand for justice. In fact, The Talented Mr Ripley is not a morality play but a bizarre, grotesque spectacle of disintegration. In this book the American writer vividly illustrates how Ripley, a confirmed psychopath imposes his own code of ethics on a world which, with few exceptions, offers little resistance. It is in Europe where his repressed, hidden desires are fulfilled and his personal ambi- 
tions are realised. It ought to be pointed out that Ripley is a new kind of criminal, not seen before in crime fiction - his nearest relatives and models being the protagonists of Marquise de Sade, whose criminal libertines challenge what we understand by good and evil, and also thrive unpunished. Patricia Highsmith frequently identified herself with her anti-hero, and throughout the plot, she polished his complex personality by placing him in chaotic situations, or else assigning to him bizarre, incomprehensible actions.

Not unlike The Talented Mr. Ripley's examination of the fluid nature of the murderer's identity and a reconstruction of his self in a new social environment, The Tremor of Forgery discusses the problem of self, identity, crime and ethics in the context of cultural shock, particularly the clash between the Western and Arab world. The novel was first published in the UK in 1969. It is Highsmith's thirteenth novel, a study in cultural and political disparity and their effect on visiting long-term residents in a foreign country. In this work the emphasis is placed on the internal world of the characters. Despite its exotic and desert landscape setting of Tunisia, The Tremor of Forgery covers some familiar territory for Patricia Highsmith. Like all of Highsmith's work, it is written in the third person, but the story is told from the perspective of a single character - as opposed to the often-adversarial viewpoints of two (usually male) protagonists - that of thirtyfour-year-old Howard Ingham, a divorced American writer staying in Tunisia. Ingham is in North Africa to work on a screenplay, but his plan is derailed when the film's backer, John Castlewood, commits suicide. Shaken by the news, Ingham nevertheless elects to stay in Tunisia and work instead on his next novel, and from here the story details his experiences in and around Tunis, as he meets and befriends another American, Francis J. Adams, and a Dane, Anders Jensen, all the while waiting to hear from his girlfriend back home, Ina. Cut off from America, with only letters to rely on for information, Ingham frets over the lack of communication from Ina. There is a hint of espionage, as Adams is revealed as an agent provocateur and propagandist, broadcasting pro-American messages on a transistor radio. And there is the question of an attempted break-in at Ingham's hotel bungalow, during which Ingham uses his typewriter as a weapon against the intruder, and after which he is unsure of the invader's fate, and is haunted by the notion that he might have killed the man, the body having been dragged away by the intruder's accomplices. Ingham struggles to keep this incident secret from his acquaintances while at the same time questioning Western morality, in particular the application of its principles in a country where he lives as a stranger. Nevertheless, he does nothing other than to discuss the events in a rather vague manner with his true friend and confidante, Jensen. Nonetheless, Adams gets word of the attack and begins to suspect that Ingham is trying to cover up the murder of a local thief and outcast who has recently vanished. Adams then shares his thoughts with Ina thus turning her visit from one of a reunion with her lover to one of suspicion, mistrust and betrayal.

Although The Tremor of Forgery is regarded as one of Highsmith's less wellknown works and is unjustly overlooked these days in favour of Highsmith's 
better-known novels, like Strangers on a Train, The Talented Mr Ripley, The Blunderer or The Cry of the Owl, Graham Green described the book as Highsmith's finest novel. In fact, it is dark and sombre, its ending ambiguous, and the emphasis is placed on the interior worlds of the protagonists. Added to that, it is a moody and disturbing excavation of guilty paranoia, and the author's inverted version of guilt that creates tension. According to Andrew Wilson, the unsettling nature of her prose is achieved not through sensational, thrilling, violent or dramatic action but an uneasy sense that nothing is certain and conclusive, that character, language and beliefs are fluid and subject to change (Wilson 2003: 277). Similar to Camus's L'Étranger, this novel by Highsmith is an unnerving study in alienation, an examination of a man and his identity in a hostile environment which strips him of his morals, breeds doubt and anxiety, and even forces the protagonist to question the nature of his sexuality. In view of this, Wilson rightly argues that The Tremor of Forgery ought to be read not as a work of crime fiction but as a serious, non-genre novel (Wilson 2003: 277-278).

The American author strikingly illustrates Howard Ingham's self-imposed exile in Tunisia, his beliefs, ethics and conscience in confrontation with a new environment, unforeseen and unavoidable circumstances which turn out to be a turning point in his personal and professional life. The most significant aspect of the novel is the question of identity, what is authentic and real and what is fake and illusory. It becomes visible when the main character, forced to leave work on a film script, decides to stay in Tunisia to focus on a novel that he originally titles The Tremor of Forgery. Ingham's book features a protagonist, Dennison, who exemplifies characteristics common to other of Highsmith's heroes, such as Tom Ripley, Sydney Bartleby or David Kelsey, insofar as he endeavours to lead a double life, and also in that it thematically raises issues of moral limits and transgressions (Peters 2011: 97): "His book was about a man with a double life, a man unaware of the amorality of the way he lived" (Highsmith 1990: 10). One can notice that, similar to Highsmith herself, Howard occupies a world confused by the regular intertwining of reality and fantasy, an environment in which it is almost impossible to decide what is fake and what is authentic. Its most vivid illustration is Ingham's confronting the vacuity of his own perceived identity and Dennison's double life. Just as Howard's loss of identity reflects Dennison's, so his life starts to parallel the triangular scenario he had constructed in his synopsis for Trio, the film he had aimed to make with John Castlewood. More importantly, the boundaries between the real and the created become even more vague after the typewriter incident, when the Arab boys working in the hotel consistently deny all knowledge of the attack and it becomes relegated to the domain of illusion (Wilson 2003: 278). Thus, living even temporarily in an alien environment has contributed to the protagonist's gradual loss of self.

As Joan Schenkar observes, The Tremor of Forgery is a profoundly American and therefore inescapably moral examination of those cultural crossings at which ethics begin to founder and violent, cruel acts, such as murder, become utterly insignificant (Schenkar 2009: 386). In this novel the American writer clearly shows 
that Ingham, finding himself in unfamiliar climes, without the support of his customs and language, a stranger in a strange land, feels compelled to adapt to the rules of the local community in Tunisia, even if they are unethical and contrary to his sense of justice. To take the analogy further, the protagonist begins to believe that he should not be held accountable for the crime he committed since it is the man's firm conviction that his act was fully justified. The same holds true for the main character of his book: "His theme was an old one, via Raskolnikov, through Nietzsche's superman: had one the right to seize power under certain circumstances? That was all very interesting from a moral point of view" (Highsmith 1990: 66). Highsmith's crucial concerns in this novel, as in her other works, are the psychology of crime, guilt, and the writer's pondering over the relativity of morality and ethics in a given situation. Adverse circumstances have led to the reconstruction of Ingham's identity, and living in a hostile environment has washed all traces of his self away. What may strike critics and the reading public is the way in which Ingham lacks a sense of moral responsibility for his killing of Abdullah. In fact, scenes showing the local men's unwillingness to investigate the murder of their colleague and bring the culprit to justice reinforce a lack of concern for human life that the protagonist believes characterizes the Arab population in Tunisia. Hence, Ingham's reluctance to admit openly he has contributed to the intruder's death.

Highsmith's novel painstakingly examines inverted morality and a troubled conscience in the face of crisis situations. Howard blames the ambience, Tunisian's climate and community customs, for his lack of initiative, absence of remorse and his refusal to take responsibility for his "inversion of things" (Highsmith 1969: 229). The protagonist endeavours to justify his violent act and clear his conscience by attributing any existing evil and negative emotions to his environment: "But was this feeling due to some strange power of Tunisia to distort everything, like a wavy mirror or a lens that inverted the image, or was the feeling valid?" (Highsmith 1969: 229). Nevertheless, Adams disturbs and disrupts Ingham's attempts at self-justification, not solely though his conscious attempts to appeal to Howard through his own individual set of beliefs and moral values, but by the mere fact of his presence. Peters rightly observes that the character of Francis Adams is pivotal to the novel, despite the fact that he may at first reading appear peripheral. Similar to Porfiry Petrovich from Crime and Punishment, Adams assumes the role of detective, moral guide and Ingham's conscience which the protagonist is able to confront only within the fiction of his own novel (Peters 2011: 99). Adams's moral as well as political beliefs are clearly defined, however, one cannot fail to notice that while attempting to make Ingham confess to the murder of the Arab, he does not intend to bring Howard to justice. In fact, for Adams, Ingham's confession has nothing to do with a concept of justice for the dead Arab but with the notion that admittance to guilt is beneficial for the soul and that his Western (Christian) system of ethics and values ought to be carefully preserved (Peters 2011: 98). Francis Adams expects from his friend a moral cleansing, while he is not concerned with law and public justice. In this regard 
he articulates Highsmith's philosophy encapsulated in the statement: "I find the public passion for justice boring and artificial, for neither life nor nature cares whether justice is ever done or not" (Highsmith 1990: 51).

Howard Ingham's lack of any sense of moral responsibility for the murder of Abdullah as well as his disrespect and disdain for Tunisia, its community and local customs closely mirror Highsmith's condescending attitude towards the country and the whole Arab culture. This is undoubtedly her most critical portrait of a foreign land, a reflection of her poignant travelling experience. Making a reference to her own status as an outsider, she describes the experience of an American writer in Africa, his alienation and cultural dislocation. The novel is a striking illustration of the situation of an expatriate, a stranger in a strange land, living in the museum of his imagination (Schenkar 2009: 385). More importantly, in the scene describing Howard committing the murder by throwing his typewriter at the head of the intruder, readers may easily notice his creator's pleasure in the act: in fact, the author expresses concern only for the typewriter and not for the deceased Arab:

Ingham gave a deep, shuddering sigh. Then he heard again soft footfalls in sand, a sound as soft as cotton. There was another faint slap, different. Someone was wiping the tiles with a rag. Wiping away blood, Ingham knew. He felt slightly sickened. The soft tread went away. Ingham waited, made himself count slowly to twenty. Then he set his reading lamp on the floor, so its light would not show much through the shutters, and turned it on. He was interested in his typewriter. (Highsmith 1969: 98)

As seen from the above excerpt, the protagonist distances himself from the crime scene, endeavouring to expunge the memory of the victim's presence and almost automatically directs his full attention to the typewriter. This fragment, along with the ensuing scenes picturing local men's reluctance to investigate the murder case and their lack of concern for a human life in Africa illustrate Highsmith's text's perversion of ethics and morality, and her style suggests the author's tacit consent to crime and the creator's pleasure in the act in adverse circumstances. It is her manipulative narration which seduces us to see only the 'primitive', barbarian Arab country, the place which transforms a genteel, civilised man into an animal-like creature who senses the freedom of having no self-respect to worry about (Schenkar 2009: 386). Thus, the American writer makes us believe that in certain alien, hostile environments a man is not or should not be held accountable for some criminal acts. Such an ambiguous attitude to crime and guilt evokes a variety of conflicting emotions in the readers who find difficulty in seeing the utter impunity of the murderers.

Overall, The Tremor of Forgery is an in-depth study of crime, guilt and ethics but first and foremost the complexity of intercultural communication, specifically the unbridgeable gap between Western and Arab cultures. Similar to The Talented Mr Ripley, in this novel one can hardly identify or sympathise with one of the protagonists since the author skilfully perverts the workings of sympathy 
towards the main characters by depicting them and their relations as queer and bizarre. Most of all, this book is an unnerving study in alienation, a scrutiny of an outsider's unsettling experience in a hostile foreign land, which in certain dire circumstances makes him operate outside the norm and live on the fringes of society.

All things considered, a reconstruction of identity, questions of ethics, morality, crime and guilt in new socio-cultural contexts are crucial notions and common denominators in Patricia Highsmith's The Talented Mr Ripley and The Tremor of Forgery. In these two novels the American author purposefully breaks the Dostoyevskian causal chain linking guilt to culpability on the one hand, and the latter to punishment which entails the possibility of redemption on the other. In this respect, her books do not function as morality plays, contrary to the movie adaptations, but rather as masterfully created amoral internal psychodramas. In the article I have shown how Patricia Highsmith's deeply conservative American background, her living in an era of social-political conformity and moral propriety, influenced her writing, life overseas and her attitude towards ethics and morality in the face of crisis situations and unavoidable circumstances. It is undoubtedly this experience which shaped her description of characters who shift and lose their true identities while committing acts of murder, and who operate outside the norm while living in lands of exile and hostile foreign environments.

\section{References}

Cassuto, Leonard (2009) Hard-boiled Sentimentality. New York: Columbia University Press.

Greene, Graham (1970) "Foreword" to Patricia Highsmith, Eleven. London: Heinemann.

Hart, Kate (2011) "In which Patricia Highsmith endures a depression equal to hell. The inner life of Patricia Highsmith." ThisRecording.com. 14 July 2015. Accessed on http://thisrecording.com/ today/2011/8/15/in-which-patricia-highsmith-endures-a-depression-equal-to-hell.html (date of access 10 September 2014).

Highsmith, Patricia (1990) Plotting and Writing Suspense Fiction. Boston: St. Martin's Griffin.

Highsmith, Patricia (1955) The Talented Mr Ripley. New York: Vintage.

Highsmith, Patricia (1969) The Tremor of Forgery. London: Virago.

"Patricia Highsmith - Exhibition Themes", Swiss National Library, Federal Administration, 10 March - 10 September 2006 Accessed on: http://www.nb.admin.ch/aktuelles/ausstellungen_und_ veranstaltungen/00820/01075/01131/index.html?lang=en (date of access 4 September 2014).

Peters, Fiona (2011) Anxiety and Evil in the Writings of Patricia Highsmith. Farnham, Burlington: Ashgate Publishing Company.

Rubin, Martin (1999) Thrillers. Cambridge: Cambridge University Press.

Sartre, Jean-Paul (1947) Existentialism, trans. Bernard Frechtman. New York: Philosophical Library.

Schenkar, Joan (2009) The Talented Miss Highsmith. The Secret Life and Serious Art of Patricia Highsmith. New York: Picador.

Torrijos, Maria del Mar Ramón (2012) "The dynamics of lesbian crime fiction”. Estudios Ingleses de la Universidad Complutense (20), 61-74.

Tuss, Alex (2004) "Masculine identity and success: A critical analysis of Patricia Highsmith's The Talented Mr. Ripley and Chuck Palahniuk's Fight Club." Journal of Men's Studies. (2 Dec. 2004) 
Accessed on http://michaelmiller.wiki.uml.edu/file/view/masculine+identityripley $\% 26 f i g h t+c l$ ub.pd (date of access 20 August 2015).

Wilson, Andrew (2003) Beautiful Shadow: A Life of Patricia Highsmith. London: Bloomsbury.

Joanna Stolarek, $\mathrm{PhD}$, is an Assistant Professor, teacher of English and American literature and culture in Siedlce University of Natural Sciences and Humanities, Poland, the author of the monograph on Martin Amis, over 35 articles on Flannery O'Connor, Katherine Anne Porter, Carson McCullers, Truman Capote, T. S. Eliot, Ezra Pound, Paul Auster, Jorge Luis Borges, as well as the editor of 5 monographs on Anglophone literature and culture. In her postdoctoral project she examines labyrinth in the metaphysical detective fiction in the USA, France and Ireland. She is a member of Polish and European Associations for American Studies and Crime Studies Network. Her academic interests include postmodern crime fiction, Southern Gothic, American modernist poetry, film studies.

Address: Dr Joanna Stolarek, Nowolipie 21/29, 01-002 Warsaw, Poland. [email: jeannemarie.stolarek@gmail.com] 